\title{
Africa Rising: (Re) interrogating the veracity and character of the Renaissance narrative
}

\author{
George Morara \\ University of Nairobi \\ DOI: 10.31364/SCIRJ/v6.i9.2018.P0918559 \\ http://dx.doi.org/10.31364/SCIRJ/v6.i9.2018.P0918559
}

\begin{abstract}
The Africa rising narrative has since 2000 been used to propagate and reinforce the idea that Africa is experiencing a renaissance as a consequence of increased economic growth, political pluralism and liberal democracy. Although some counties have experienced positive change, the validity or veracity of the idea is now questionable given recent events across the continent - from Libya to South Africa, South Sudan to Kenya, Somalia, Ethiopia, Nigeria, Mali to the Democratic Republic of Congo, and others paint a bleak picture of the continent with rising levels of poverty, corruption, conflict and civil war among other challenges. This article problematizes the concept of Africa rising, and argues that although Africa has experienced positive economic and political developments, the renaissance narrative has been used to propagate a myth that is meaningless to a majority of Africans.
\end{abstract}

Keywords: Africa rising, Africa Renaissance, economic growth, democracy, political and economic myth

\section{Introduction}

On March 21, 2018, 44 African countries signed a trade pact that would ostensibly have huge business, economic, political and social implications across the continent. The African Continental Free Trade Area (CFTA) will reportedly create a $\$ 3$ trillion continental free-trade zone encompassing 1.2 billion people by removing barriers to trade, like tariffs and import quotas, and allowing a free flow of goods and services between its members. "This is a historic pact which has been nearly 40 years in the making, and it represents a major advance for African integration and unity," said Paul Kagame, the President of Rwanda and new Chairperson of the African Union (AU) at an extraordinary summit of the Union in his country's capital Kigali. This was echoed by Moussa Faki Mahamat, Chairperson of the African Union Commission who opined during the opening of the signing ceremony of the meeting that "our peoples, our business community and our youth, in particular, cannot wait any longer to see the lifting of the barriers that divide our continent, hinder its economic take-off and perpetuate misery, even though Africa is abundantly endowed with wealth.”

The optimism was, however, tempered with some skepticism from Africa's two biggest economies, Nigeria and South Africa, which did not sign up. Nigeria's President Muhammadu Buhari said in a series of tweets that his country was still consulting to "ensure that all concerns are respectfully addressed". Two tweets read: "Nigeria fully recognizes and appreciates the efforts of the African Union Commission so far, regarding the implementation of a sustainable Continental Free Trade Agreement (CFTA) for Africa. We also acknowledge that our continental aspirations must complement our national interests". In the second tweet he said: "As Africa's largest economy and most populous country, we are committed to ensuring that all trade agreements we sign are beneficial to the long-term prosperity of the continent. 
We are therefore widening and deepening domestic consultations on the CFTA, to ensure that all concerns are respectfully addressed. Any African free trade agreement must fairly and equitably represent the interest of Nigeria, and indeed, her African brothers and sisters".

Despite the fact that Nigeria and South Africa did not sign up and there are fears that this could diminish CFTA's impact, there are suggestions that the initiative is a game changer that would enhance the idea of African Renaissance and promote the Africa rising narrative. Such optimism is, however, often tempered by serious pessimism about the practicalities of some initiatives in a continent plagued by numerous challenges occasioned by such issues as conflict, poor political and economic governance, corruption, lack of accountability and transparency in the management of state and government affairs, and poverty. This conclusion is partly borne out by President Buhari's tweets, in addition to recent events, which denote some reluctance, pessimism and even resistance to continent-wide initiatives meant to promote development across Africa. Conflicts in South Sudan, Libya, Somalia, human rights abuses in the Democratic Republic of Congo, Ethiopia, Burundi, corruption in South Africa, Zimbabwe, Kenya, Malawi and other countries paint a picture of failure. Granted, some countries, like Rwanda, have emerged out of the ashes to become stable and successful. Such conflicting observations point to the fact that Africa is not homogenous and that there is need to reexamine some of the conclusions often bandied about the continent some of whose countries often move from economic growth and development, stability to underdevelopment, misery, famine, poverty and hopelessness.

While this article does not pander to either optimism or pessimism regarding development initiatives, and optimistic narratives couched in such labels as Africa rising and Africa Renaissance, it argues that it is imperative to consider the realities in the continent before propagating or advancing some 'meaningless' labels and myths.

\section{The media's role in articulating the Africa rising 'myth'}

Ideas of Africa rising and Renaissance have been used - particularly in investment and marketing events and conferences - to market the continent as the new investment hub. For example, giving a keynote speech at the Africa Rising Business Conference held at INSEAD Fontainebleau on June 15, 2012, Mo Ibrahim, the Chair of the Mo Ibrahim Foundation and chairman of Satya Capital, an investment firm that focuses on Africa, proclaimed Africa "the last frontier ... If you really want to make money you have to be there."

Since about 2000, the terms Africa rising and Renaissance have been in vogue as leaders, public relations experts hired to market Africa and others romanticized the continent because of the apparent opportunities available for exploitation. In addition, the African rising narrative has been popularised by the media which seems seduced by reports of economic growth, technological penetration and appropriation, and political pluralism and democratization. Reports by such organisations as the World Bank 
Group and the International Monetary Fund often draw optimistic conclusions which are then picked and popularized by the mass media. Reports that Africa's economy grew by 50 per cent in contrast with a world average of 23 per cent between 2005 and 2015 are especially attractive to the media seeking 'good' and sellable stories.

Contradictory media reports and conclusions bear out the arguments above. For example, the internationally respected The Economist magazine declared Africa, on its May 2000 print edition cover, a hopeless continent. In that article, the magazine wrote that "the new millennium has brought more disaster than hope to Africa. Worse, the few candles of hope are flickering weakly"1 and posed: "Does Africa have some inherent character flaw that keeps it backward and incapable of development?" 2 Robert Guest, who served as the magazine's Africa Editor, later published The Shackled Continent detailing the challenges facing Africa and concluded, like other Western journalists, that Africa was doomed and its future bleak. ${ }^{3}$

The Economist, however, changed tune in December 2011 with a cover title 'Africa rising', predicating that the continent was ready for takeoff because of rapid economic growth, rising incomes and an emerging middle class, and improved 'accountable' and 'progressive' political and economic governance. In its leaders section, the magazine argued that Africa's growth rate was impressive because of numerous factors, including rising global commodity prices, manufacturing and service economies. "Over the past decade six of the world's ten fastest-growing countries were African. In eight of the past ten years, Africa has grown faster than East Asia, including Japan. Even allowing for the knock-on effect of the northern hemisphere's slowdown, the IMF expects Africa to grow by $6 \%$ this year and nearly $6 \%$ in 2012 , about the same as Asia," The Economist wrote. ${ }^{5}$ These trends were supported by growing political pluralism, openness and democracy across the continent. Other media that had hitherto demonstrated apathy towards Africa - beyond the negative stories of hunger, corruption, conflict, civil war, autocracy, and poor governance, among others - started showing interest in the continent too. Time Magazine had on its cover the Africa rising title in 2012. Many conferences, among them the high level Africa Rising conference organised by the Government of Mozambique and the International Monetary Fund (IMF) in Maputo, jumped into the bandwagon. The 29-30 May 2014 Africa Rising conference took stock of what it called Africa's apparent strong economic performance, and increased resilience to shocks alongside economic policy challenges.

Media, optimistic scholarly studies, international non-governmental organisations reports, conferences and other events contributed to the popularization of the Africa rising narrative. Thus reports abound that there are now more middle class (a person living on $\$ 10-\$ 100$ a day according to the African Development Bank) Africans, that the proportion of wealthy Africans has increased, and that more Africans are out of poverty. Many reports also point to the rapid diffusion of technology and mobile telephony and indicate that one in three people use mobile phones. And more important is the fact that good political governance has grown with more 'democratic' elections in which women have greatly benefited with more leadership positions. Rwanda is 
hailed as a trendsetter for having the largest number of female MPs in the world. The Rwandan case is of course true. As of January 2017, Rwanda had 49 women in its 80- seat lower house and 10 women in its 26-seat Upper house of parliament. According to statistics from UN Women, six other African countries ranked highly in terms of the percentage of women in their parliaments. Senegal, South Africa, Namibia, Mozambique, Ethiopia and Angola were ranked 7, 9, 12, 13 , 17 and 19 respectively. ${ }^{6}$

However, since the term Africa rising first gained popularity, it has been used and misused and become a cliché of sorts. Given the development differentials across the continent, from relatively stable economic and democratic environments in some countries, to fluid and conflicting situations, Africa is full of contradictions.

\section{Reality versus fallacy}

The Africa rising narrative has recently become problematic for various reasons, and some have started question the accuracy of the label. Even the most optimistic Africanist scholars now doubt the veracity of the term. Cramer and Chang have, for example, pointed out that "the African growth tragedy and the more recent narrative of Africa rising are both unwarranted, preventing a more realistic approach to understanding the challenges and prospects of long-term economic development in the continent." This view is supported by Ian Taylor who argues that "given the weak levels of diversification and strong concentrations in specific export sectors, it is remarkable that a narrative has been but that claims that Africa is 'rising' in the absence of any indication of widening domestic manufacturing based or actual industrialization". ${ }^{8}$

In addition to the arguments above, pictures of people crossing from Africa to Europe in dangerous dinghies in the Mediterranean Sea and deaths in the hands of people smugglers and criminal gangs/cartels demonstrate a failing Africa where people are willing to risk their lives to escape poverty or political persecution in the hands of dangerous dictators or intolerant leaders.

An article in the New York Times in 2016 headlined 'Africa Rising'? 'Africa Reeling' May Be More Fitting Now, seemed to pour cold water on the narrative of Africa rising. ${ }^{9}$ In the article, Jeffrey Gettleman posited that:

For so long Africa had been associated with despair and doom, and now the quality of life for many Africans was improving. Hundreds of thousands of Rwandans were getting clean water for the first time. In Kenya, enrollment in public universities more than doubled from 2007 to 2012. In many countries, life expectancy was increasing, infant mortality decreasing. But in recent months, as turmoil has spread across the continent, and the red-hot economic 
growth has cooled, this optimistic narrative has taken a hit. Some analysts are now questioning how profound the growth actually was. No place exposes the cracks in the "Africa rising" narrative better than Ethiopia, which had been one of the fastest risers. Ethiopia is now in flames. Hundreds have been killed during protests that have convulsed the country. ${ }^{10}$

Yet despite conclusions that Ethiopia is in 'flames', it has been used to illustrate the African rising narrative. Reports indicate that it has one of the best performing economies in Africa, with a double-digit growth rate, averaging 10.3 percent a year from 2005 to 2016. ${ }^{11}$ Other reports, for example, the United Nation's World Economic Situation and Prospects 2018, indicate that the economic growth in Ethiopia is expected to be 7.3 percent and 7.5 percent in 2018 and 2019 respectively. ${ }^{12}$ The World Economic Situation and Prospects 2018 is produced by the United Nations Department of Economic and Social Affairs (UN/DESA), the United Nations Conference on Trade and Development (UNCTAD) and the five United Nations regional commissions (Economic Commission for Africa (ECA), Economic Commission for Europe (ECE), Economic Commission for Latin America and the Caribbean (ECLAC), Economic and Social Commission for Asia and the Pacific (ESCAP) and Economic and Social Commission for Western Asia (ESCWA)). Despite being the fastest growing, it is reported to be one of the poorest in Africa with a per capita income of $\$ 783$ (World Bank Group, 2018). With a population of over 100 million, Ethiopia has a large number of people below the poverty line, and millions still rely on food aid for their survival. ${ }^{13}$

Overall, Africa's economies grew at a rate of 4.9 percent between 2000 and 2008, a huge leap from the rates experienced in the 1980s and 1990s. ${ }^{14}$ An African Economic Outlook 2013 report done by the African Development Bank (AfDB), Development Centre of the Organisation for Economic Co-Operation and Development (OECD), the United Nations Development Programme (UNDP) and the Economic Commission for Africa (ECA) indicates that Africa's exports almost quadrupled in value, from USD 148.6 billion a year to USD 581.8 billion from 2000 to $2011 .^{15}$

Conclusions of contractions are borne out by reports indicating that the Democratic Republic of Congo's growth rate is impressive, and is second to Ethiopia. Although DRC is one of the richest countries in the world in terms of mineral resources, it has been a theatre of conflict, suffering, and misrule and reports of growth do not seem to take this into consideration. Thousands of people are killed in DRC each year, and its history is characterised by civil war, corruption, disease, malnutrition, plunder and suffering. Civil war has killed more than six million people, "either as a direct result of fighting or because of disease and malnutrition ...."16

The respected British Broadcasting Corporation (BBC) labels the civil war in DRC as 'Africa's world war' because it has drawn in several neighbouring countries. The war that has raged since the autocratic and psychopathic leadership of Mobutu Sese Seko 
was disposed in 1997 by Laurent Kabila, the father of the current leader Joseph Kabila. The younger Kabila became president when his father Laurent was assassinated in 2001. He was elected in 2006, and secured another term in controversial elections in 2011. Although his second and final term officially ended in December 2016, he has either refused to hold elections or leave power. After intense pressure, Kabila finally gave in and announced that he will not be in the ballot in the elections scheduled for 23 December 2018. Mobutu was in power between 1965 and 1997, and was notorious for monopolizing power, violence and amassing a vast personal fortune. ${ }^{17}$ The BBC describes the country as “ ... a vast country with immense economic resources and, until recently, has been at the centre of what some observers call "Africa's world war", with widespread civilian suffering the result. The war had an economic as well as a political side. Fighting was fuelled by the country's vast mineral wealth, with all sides taking advantage of the anarchy to plunder natural resources. ${ }^{18}$

Ethiopia, and DRC are part of a number of countries in Africa that have and continue to face serious challenges particularly with regards to civil war and/or conflict, corruption and misrule. Images from South Sudan and Libya, for example, point to cases of either failed or failing states. For example, South Sudan has suffered serious conflict since 2013, just two years since it gained independence from Sudan in 2011. In December 2013, the country saw the breakout of severe fighting between government forces and the opposition in a civil war that has reportedly killed thousands of people and displaced more than three million people from their homes. The conflict is exacerbated by tensions between the government under the Sudan People's Liberation Movement and Army in Government (SPLM/A-IG) and opposition (SPLM/A in Opposition (SPLM/A-IO). More specifically, the conflict involves, among others, the military under President Salva Kiir and supporters and the rebel movement led by former Vice President and opposition leader Dr. Riek Machar. The situation is complicated further by the recent formation of another rebel movement - the South Sudan United Front - by the former military chief Paul Malong. The conflict also involves fighting among various ethnic groups, particularly the Dinka of President Kiir and Nuer of Dr. Machar. Consequently, there have been mass killings along ethnic lines which have worsened the situation and increased tensions among the communities. In essence, the conflict is fuelled mainly by the struggle for resources and power, historical ethnic tensions, and the inability and/or failure of the government and the opposition to protect civilians from violence.

A 2018 Human Rights Watch report on South Sudan points out that:

Since the start of the conflict, almost 2 million people have been internally displaced, and another 2 million have sought refuge in neighboring countries, with 1 million in Uganda alone. More than 230,000 people are sheltering in six United Nations bases in towns across the country. Famine was declared in conflict-affected areas in the former Unity state in the first half of the year. The war began as a political conflict between President Salva Kiir and his then Vice President Riek Machar in December 2013. A power sharing agreement, signed between the two parties in August 2015, did not end the fighting; following clashes in Juba in July 2016, Machar went into exile, where he remains. Both sides have committed abuses that qualify as war crimes, including looting, indiscriminate attacks on civilians and the destruction of civilian property, arbitrary arrests and detention, beatings and torture, enforced disappearances, rape including gang rape, and extrajudicial executions. Some abuses may also constitute crimes against humanity. ${ }^{19}$ 
The examples above are sometimes dismissed by African optimists and leaders who see Western media as part of a conspiracy that hardly sees anything positive out of Africa. Yet as evidence points out above, the suffering experienced as a consequence of conflict and civil war, poverty and corruption, misrule and autocracy in parts of Africa tells a negative story of the continent that cannot be rising.

While it is acknowledged that the quality of life and standards of living has improved for many in the last two decades, there are contradicting images of the continent that partly reinforce notions that the narrative is either problematic or indeed dead. These conclusions are based on recent developments in the continent that on the whole paint a glim picture of Africa.

Besides, as debates rage on the meanings of such developments, argument suggest that the rates of development in Africa are a consequence global trends or developments. For example, arguments suggest that the impressive economic development rates in Africa are a consequence of the growth in manufacturing and service economies ${ }^{20}$ and "commodity price boom that was unprecedented in its magnitude and duration. The real prices of energy and metals more than doubled in five years from 2003 to 2008, while the real price of food commodities increased $75 \% " .{ }^{21}$ The price boom was thus partly natural given the new trading geographies and the emergence of 'non-traditional' actors in Africa ${ }^{22}$ which might be difficult to keep up if the demand for commodities drops. Thus while Africa has seen a rise in living standards, what Taylor (2014) suggests is that this was expected, and was not a result of new strategies or thinking from African countries, governments, political leaders or economists. ${ }^{23}$ Besides, do increasing GDPs rate translate to real monetary gains for the ordinary people. According to the World Bank, for example, "half of the extreme poor people in the world live in Sub-Saharan Africa ... with 389 million people living on less than US\$1.90 a day in 2013, more than all the other regions combined". ${ }^{24}$ (World Bank Group, 2018). The grim picture was exacerbated by another which indicates that nearly half of all children in sub-Saharan Africa live in extreme poverty. ${ }^{25}$ The consequences of such poverty are huge, including for example, stunted development, limited future productivity as adults, and intergenerational transmission of poverty. ${ }^{26}$

Indeed as Tom Burgis contends in his book The Looting Machine: Warlords, Tycoons, Smugglers and the Systematic Theft of Africa's Wealth, even though Africa is both the world richest and poorest continent. ${ }^{27}$ He argues that while it only accounts for just two percent of the global gross domestic product, it has a third of the earth's mineral deposits, with 15 percent of the world's crude oil, 40 per cent of its gold and 80 per cent of its platinum. ${ }^{28}$ But as the title suggests, Africa is awash with thieves, warlords, tycoons and smugglers who steal its wealth for personal gain and enrichment. What's more, as the arguments above indicate, the impressive economic growth rates do not necessarily translate to wealth and are thus meaningless to a many people who still have to scavenge for food or rely on hand out from government and international aid organisations. This view is supported by others who see the Africa rising narrative as 'meaningless' in a continent where poverty, corruption and misrule abound. For example, 
Wadongo suggests that "Just because some African economies are recording annual growth rates of more than $6 \%$ does not mean that the lives of average citizens are necessarily improving apace; wealth disparity is rising even faster". ${ }^{29}$ Accordingly, it is imperative to evaluate African economies individually, on country-specific fundamentals. In other words, as Coulibaly correctly points out, "“'Africa rising” does not mean "all” African countries are rising" 30 and thus the need to critically reevaluate the basis upon which some of the fallacious arguments and conclusions are based. As The Economist warned in 2011:

Optimism about Africa needs to be taken in fairly small doses, for things are still exceedingly bleak in much of the continent. Most Africans live on less than two dollars a day. Food production per person has slumped since independence in the 1960s. The average lifespan in some countries is under 50. Drought and famine persist. The climate is worsening, with deforestation and desertification still on the march. Some countries praised for their breakneck economic growth, such as Angola and Equatorial Guinea, are oil-sodden kleptocracies. Some that have begun to get economic development right, such as Rwanda and Ethiopia, have become politically noxious. Congo, now undergoing a shoddy election, still looks barely governable and hideously corrupt. Zimbabwe is a scar on the conscience of the rest of southern Africa. ${ }^{31}$

Although the article is years old, it reflects the goings-on in some parts of the continent that seem to reinforce the skeptics position that the Africa rising narrative is an dead in the face of the political and economic plaguing the continent.

\section{Media complicity}

In 2016, Lily Kuo argued that the African rising narrative was a myth and marketing gimmick and strategy meant to "widen the investment appeal of another swathe of emerging markets". ${ }^{32}$ This argument would seem to support the notions of Africa being the new frontier for both investment and exploitation and thus the need to develop new strategies such as CFTA to potentiate its place in a globalized world.

Questions thus abound about the veracity of the Africa rising narrative, and the role of the media in popularizing the narrative. Is the media competent in determining and critically interrogating issues relating to development, and does it offer evidence to support reports and conclusions supporting claims of Africa rising? Is the media advancing particular agendas and ideologies based on real reality of assumed realities pushed by certain actors and sources? Is the media capable of offering coherent and logical explanations for its conclusions?

That the media has always been complicit in political agendas is not in doubt. While there is some truth that the media is a critical actor in development ${ }^{33}$ and provides the important information and platform for sharing information, discussions and contributes to the aggregation and formation of public opinion, ${ }^{34}$ debates abound on whether the media is trustworthy in an era when their (especially normative) roles are increasingly under the spotlight. 
The media's role in Africa has largely been to report 'accurately', often without critically interrogating the information and statistics, and problematizing the issue. Because of this, the notion of African rising has been unquestioningly accepted. For example, as indicated above, the media often focuses on negativity and thus most of the articles and images of Africa, particularly in the international media, are of the bad news. In essence, the representation of Africa in the media as hopeless, desperate, corrupt, and as a place ravaged by conflict, war, terrorism and poor political leadership seems commonplace despite concerns that such portrayal is not only condescending but also derogatory or offensive. Notwithstanding recent attempts to reimagine the continent image and profile, problems still abound and examples of conflict in places like South Sudan, Libya, Central African Republic, and terrorism in Kenya, Somalia and Nigeria, autocratic leadership in DRC, Eritrea, Zimbabwe, The Gambia and others regularly make 'good' news for most media, both African and international. Consequently, ideas such as African Renaissance, African rising and Africa's century are seen as mere labels that are not reflective of current realities.

\section{Conclusion}

Since the Africa rising narrative was coined almost two decades ago, a lot has changed in the continent, and there are doubts about its veracity given recent developments and goings-on. For example, while the narrative was grounded on economic growth, technological developments, appropriation and effects, and political pluralism and democracy, recent events, particularly the rise of conflict, poverty and corruption, and the decline in transparency, accountability and democracy in many countries, there are feelings that the mantra is meaningless.

In addition, there are questions on whether media reports are reflective of realities across the continent, and whether the media's popularization of the African rising narrative was based on empirical evidence or merely on reports produced by organisations such as the World Bank and the International Monetary Fund that often use the media to influence and even manipulate certain discourses and opinions. Moreover, is the media capable and willing to critically or rigorously interrogate strategies and pronouncements of African leaders, public relation experts and marketers who have been part of campaigns aimed at making Africa attractive to investors.

Although there is no denying that some African countries are doing well, it is evident that the African rising cliché has somewhat become meaningless and it is time to evaluate African economies individually, on country-specific fundamentals as a way of making valid predictions and conclusions on socio-economic and political developments. 


\section{Notes}

1 The Economist. "The heart of the matter." The Economist, May 11, 2000, https://www.economist.com/node/333437.

2 The Economist. "The heart of the matter." The Economist, May 11, 2000, https://www.economist.com/node/333437.

3 Guest, Robert. The Shackled Continent: Power, Corruption, and African Lives. Washington, DC: Smithsonian Books, 2004.

4 The Economist. “Africa rising.” The Economist, December 3, 2011, http://www.economist.com/node/21541015.

5 The Economist. “Africa rising.” The Economist, December 3, 2011, http://www.economist.com/node/21541015.

6 See map at: http://www.unwomen.org/-

/media/headquarters/attachments/sections/library/publications/2017/femmesenpolitique_2017_english_web.pdf?vs=1123.

7 Cramer, Christopher and Ha-Joon Chang. "Tigers or Tiger Prawns? The African Growth "Tragedy" and "Renaissance" in Perspective.' In Monga, Célestin and Justin Yifu Lin. The Oxford Handbook of Africa and Economics: Context and Concepts. Vol. 1. Oxford: Oxford University Press, 2015, pp. 483-503. This quote, p. 500.

8 Taylor, Ian. Africa Rising?: BRICS - Diversifying Dependency. Woodbridge, Suffolk: James Currey, 2014, p.16.

9 Gettleman, Jeffrey. “'Africa Rising’? ‘Africa Reeling’ May Be More Fitting Now.” New York Times, 17 October 17, 2016, https://www.nytimes.com/2016/10/18/world/africa/africa-rising-africa-reeling-may-be-more-fitting-now.html.

10 Gettleman, Jeffrey. “‘Africa Rising’? ‘Africa Reeling’ May Be More Fitting Now.” New York Times, 17 October 17, 2016 , https://www.nytimes.com/2016/10/18/world/africa/africa-rising-africa-reeling-may-be-more-fitting-now.html.

11 McKinsey Global Institute. Lions on the Move II: Realizing the Potential of Africa's Economies. McKinsey Global Institute, 2016; World Bank Group. “The World Bank in Ethiopia.” World Bank Group, 2018b, http://www.worldbank.org/en/country/ethiopia/overview.

12 United Nations. World Economic Situation and Prospects 2018. New York: United Nations, 2018, https://www.un.org/development/desa/dpad/wp-content/uploads/sites/45/publication/WESP2018_Full_Web-1.pdf.

13 World Bank Group. “Country Poverty Brief: Ethiopia.” World Bank Group, 2017, http://databank.worldbank.org/data/download/poverty/33EF03BB-9722-4AE2-ABC7-

AA2972D68AFE/Global_POV_SP_CPB_ETH.pdf.

14 McKinsey Global Institute. Lions on the Move II: Realizing the Potential of Africa's Economies. McKinsey Global Institute, 2016.

15 African Development Bank, Development Centre of the Organisation for Economic Co-Operation and Development, the United Nations Development Programme, and the Economic Commission For Africa. African Economic Outlook 2013: Structural Transformation and Natural Resources. Paris: OECD Publishing, 2013, http://www.africa.undp.org/content/rba/en/home/library/reports/poverty-reduction/african-economic-outlook-2013.html. 16 BBC. "DR Congo country profile.” BBC, December 6, 2017, http://www.bbc.com/news/world-africa-13283212. 17 BBC. “DR Congo country profile.” BBC, December 6, 2017, http://www.bbc.com/news/world-africa-13283212. 18 BBC. “DR Congo country profile.” BBC, December 6, 2017, http://www.bbc.com/news/world-africa-13283212. 19 Human Rights Watch. World report. New York, NY: Human Rights Watch, 2018, p. 501.

20 The Economist. “The heart of the matter." The Economist, May 11, 2000, https://www.economist.com/node/333437. 21 Erten, Bilge and Jose Antonio Ocampo. Super Cycles of commodity prices since the Mid-Nineteenth Century. World Development, vol. 44 (2013), p. 4. 
22 Taylor, Ian. Africa Rising?: BRICS - Diversifying Dependency. Rochester, NY: James Currey, 2014.

23 Taylor, Ian. Africa Rising?: BRICS - Diversifying Dependency. Rochester, NY: James Currey, 2014.

24 World Bank Group. “Poverty.” World Bank Group, 2018a, http://www.worldbank.org/en/topic/poverty/overview.

25 Unicef-World Bank Group. “Ending Extreme Poverty: A Focus on Children.” Unicef, October 2016, https://www.unicef.org/publications/files/Ending_Extreme_Poverty_A_Focus_on_Children_Oct_2016.pdf.

26 Unicef-World Bank Group. “Ending Extreme Poverty: A Focus on Children.” Unicef, October 2016, https://www.unicef.org/publications/files/Ending_Extreme_Poverty_A_Focus_on_Children_Oct_2016.pdf.

27 Burgis, Tom. The Looting Machine: Warlords, Tycoons, Smugglers and the Systematic Theft of Africa's Wealth. London: William Collins, 2015.

28 Burgis, Tom. The Looting Machine: Warlords, Tycoons, Smugglers and the Systematic Theft of Africa's Wealth. London: William Collins, 2015.

29 Wadongo, Evans. “Africa rising? Let's be Afro-realistic.” The Guardian, November 7, 2014, https://www.theguardian.com/global-development-professionals-network/2014/nov/07/africa-rising-lets-be-afro-realistic. 30 Coulibaly, Brahima Sangafow. "In defense of the 'Africa Rising' narrative.” Brookings Institution, June 27, 2017, https://www.brookings.edu/blog/africa-in-focus/2017/06/27/in-defense-of-the-africa-rising-narrative/.

31 The Economist. "The heart of the matter.” The Economist, May 11, 2000, https://www.economist.com/node/333437. 32 Kuo, Lily. “Africa wasn’t “rising” before and it's not “reeling” now.” Quartz Africa, October 24, 2016, https://qz.com/816006/africa-wasnt-rising-before-and-its-not-reeling-now/.

33 Scott, Martin. Media and Development. London: Zed Books, 2014.

34 Christians, Clifford, Clifford Glasser, Denis McQuail, Kaarle Nordenstreng and, Robert White. Normative Theories of the Media: Journalism in Democratic Societies. Urbana and Chicago: University of Illinois Press, 2009; Curran, James, and Michael Gurevitch. Mass media and society. London: Hodder Arnold, 2005; McQuail, Denis. McQuail's Mass Communication Theory. 5th ed. London: Sage, 2005. 